Hanan Ahmed Hussien

\title{
The effect of using context- based learning strategy REACT on developing secondary stage students' achievement in grammar, motivation and the transfer of learning on their oral performance
}

Hanan Ahmed Hussien

Lecturer at Curricula and Instruction Department

Ain Shams University-Girls' college

\begin{abstract}
The current study aimed to determine the effect of using context-based strategy REACT on developing secondary stage students' achievement in grammar, motivation and the transfer of learning on their oral performance. The grammar lessons in the first secondary grade students' textbook for the first term were used, the teacher's guide and the student's worksheet were prepared. A grammar achievement test, a motivation questionnaire and an oral performance test were prepared as well. The study had two groups: one experimental group and one control group (first secondary grade students). The tools of the study were pre administrated to both the experimental group and control group. The prepared grammar lessons were introduced according to the steps of the context-based strategy REACT. The tools were post administered to the experimental group and the control group. The obtained data from the pre and post administration of the tools were analyzed. The statistical analysis of the data showed a large effect of the context-based strategy (REACT) on developing secondary stage students' achievement in grammar, motivation and a positive transfer of learning on the oral performance of the experimental group students.
\end{abstract}

Key words: context-based learning / REACT strategy / grammar / motivation / transfer of learning / oral performance.

\section{Introduction}

English is the first language of the six widely used languages around the world. In education, English has become the primary language of communication. It is spoken by billions of people all over the world. This important role of English has greatly contributed to the movement of teaching it as a foreign Language. Therefore, learning English has become a means of keeping up with the pace of the rapidly changing world. It is also the language of international business, diplomacy, and professions (Akbulut, 2007).

Every language in the world has its pillars and fundamentals. It is obvious that the pillars of English are its rules of grammar. To master any language in general and English language in particular, one, among other things, should learn its grammar effectively and know how to use it correctly and sufficiently (Larsen-Fensham, 2009).

The problem of grammar in the English language stems from the fact that it is taught in a separate and isolated manner and that it is not integrated with other skills or employed in a practical and vital way(Al 
Jamal, 2016). In secondary stage textbooks "Hello", grammar is very often presented out of context. Learners are given isolated sentences to explain or practice the grammar rule, which they are expected to internalize through exercises involving repetition, manipulation, and grammatical transformation. These exercises are designed to provide learners with formal, declarative mastery but without focus on grammar applications and functions in everyday life. Many studies have investigated the weakness of EFL learners in grammar and attempted to improve it; (RafiK , 2012; ElSeoud , 2013; Raftery, 2015; Hameed ,2017; and Sarac, 2018). They used different techniques like humor, contextualizing grammar, games and cloud computing technologies.

Growing numbers of studies show that most students' interest and achievement in learning languages improve when they are helped to make connections between new knowledge and experiences they have had, or with other knowledge they have already mastered. Context-based learning is a pedagogical methodology that, in all its disparate forms, centers on the belief that both the social context of the learning environment and the real, concrete context of knowing are crucial to the acquisition and processing of knowledge. The approach is based on the firm conviction that learning is a social activity (Mazzeo, 2008; Perin, 2011).

Some researchers have sought to employ different teaching strategies to help learners to apply the rules of grammar in the English language. Context-based learning was one of them as it was the source of many strategies. Massey (2011) studied the impact of teaching grammar through writing context by the students on their performance, and the results were positive. Likewise, Weaver (1996) confirmed the effectiveness of teaching grammar in context more than when it was taught through traditional methods. Dean (2008) also provided many of the strategies that could be used in teaching grammar through context.

Teaching grammar in context will give learners an opportunity to understand how language works and this will improve their communication skills (Harmer, 1991). Context gives a more precise understanding of how to use the grammar, and provides accuracy in the studied language both in oral and written skills (Byrd, 2005). Contextbased teaching will show learners how grammar structures function in context that will give them an opportunity to develop their comprehension of the grammar rules.

Using contextual learning in the classroom does not involve new tools. It involves new teaching styles and strategies. Teachers can maximize the outcomes of this type of learning by successfully applying context-based strategies such as REACT strategy in their everyday lessons. The strategy 


\section{Hanan Ahmed Hussien}

is one of strategies in contextualization proposed by (Crawford, 2001). REACT has five stages which can be elaborated as follows:

First, Relating is the fundamental stage in contextual teaching strategy. In brief, relating is a process of connecting the material with learners' experiences to their prior knowledge (Crawford, 2001).

Second, Experiencing has something to do with carrying out the material into the classroom in an attempt to give hands-on experiences. This stage is aimed at helping the students who have no relevant experience with the material that are going to be taught.

Third, Applying can be defined as the stage that gives opportunity for students to learn to put the concepts to use in a real activity (Crawford, 2001). Utomi (2016) states that through this stage, the students are able to solve the problem by putting the concept into action by answering many activities.

Fourth, Cooperating is defined as learning in the context of sharing, responding, and communicating with other students (Crawford, 2001). Zulmaulida (2011) claims that cooperating enables students to learn together; sharing their opinion and maintaining their responsibility for the learning goal.

Fifth, Transferring means learning in the context of existing knowledge, or using and building upon what the student has already learned. It refers to using knowledge in a new context or novel situation (Beaten, 2010).

Context-based strategy REACT has been employed to improve the learners' skills and achievement successfully in mathematics and science such as in the studies of ( Ültay et al., 2011; Demir \& Demircioglu, 2012; Bahtaji, 2015 ; Ültay \& Calik, 2016) but it was not used in teaching EFL grammar - as far as the researcher knows.

Student motivation is probably one of the most important elements of learning. Learning is inherently hard work; it is pushing the brain to its limits, and thus can only happen with motivation. Highly motivated students will learn readily, and make any class fun to teach, while unmotivated students will learn very little and generally make teaching painful and frustrating. Fortunately, research shows that there is a lot teachers can do to motivate their students to learn (Guay et al., 2010). Secondary stage learners need to be motivated when acquiring English as a foreign language .

Context-based approach aims to increase the enthusiasm and motivation of students in learning English through presenting its skills using authentic materials and everyday life situations (Barker, 1999). In context-based teaching, using contexts to increase students' need-toknow, creating everyday life situations, and doing in-class activities play a great role in increasing learners' motivation. The stages of REACT 
strategy increase the learners' motivation as it depends on presenting authentic materials, audio and visual aids, everyday life situations, role play, games and cooperating activities. In the current study, context-based strategy REACT is hoped to lead secondary stage learners to identify the value of learning grammar in their lives and consequently increase their learning motivation.

Transfer of learning is using previous knowledge in novel contexts. Fink (2003) defines transfer of learning as the ability to apply knowledge or procedures learned in one context to new contexts. Transfer of learning takes place when learners stop being passive note-taking and engage the material actively (Nilson, 2003). Different active learning techniques affect the engagement and general understanding of the immediate subject matter, which encourages transfer. A student who cannot understand how information can be generalized has more difficulty reflecting on how it might be used in new contexts.

Context-based learning strategies can be used effectively in transfer of learning; they present active and learner-centered learning. Context-based strategy REACT provides the learners with numerous opportunities to actively practice the learned materials. The present study aims at investigating transfer of learning grammar- using context-based strategy REACT- on secondary stage learners' oral performance.

REACT strategy promotes the learners to use the target language in communication in all its five stages. The fourth stage of the strategy in particular is "cooperating" and it requires the learners to communicate orally and negotiate the answer. Various authentic materials like videos and animation are used. Grammar learning is only meaningful and purposeful if it is used in effective communication rather than for the mastery of individual language forms. Grammar should be shown as a means to convey meaning to achieve an outcome rather than merely taught as a set of items and rules. If learners are not given opportunities to explore grammar in context, it will be difficult for them to see how and why alternative forms exist to express different communicative meanings (Liu, 2007).

This study aims at investigating the effect of using context-based strategy REACT in improving first secondary graders' achievement in grammar and motivation. It also aims at investigating the transfer of learning on their oral performance. 


\section{Hanan Ahmed Hussien}

\section{Context of the problem}

The need to conduct the current study springs from the following sources:

1- The researcher attended some English periods in two secondary schools (Al Abbassia and Ismail Al kabany) in Al Abbassia district in Cairo. She noticed the weakness of first grade secondary students in the application of grammar rules. Examining the results of the monthly exam of the students assured that $47 \%$ of the students failed to get half the mark given to grammar.

2- The researcher interviewed two English teachers in each of the previously mentioned schools and asked them the following questions:

Which part in the first grade secondary English course is the most difficult for your students?

In your opinion, what are the reasons for the low achievement level of first grade secondary students in grammar?

What are your suggestions to improve students' achievement in grammar?

In answering the first question teachers named some different areas but they all agreed on choosing grammar as one of the most difficult parts in the course. The teachers mentioned many problems with teaching grammar such as: students have difficulty in understanding and applying grammar rules- students do not value the importance of grammar in learning English- they face difficulty in differentiating the uses of tensesthey fail to use appropriate grammar in writing or speaking- the lack of suitable technologies and teaching aids to help in presenting grammar in an authentic and appealing way. They suggested presenting grammar in meaningful and interesting context to learners using authentic materials and audio visual aids. They also stressed the importance of helping the students to use the grammar they learn functionally to communicate orally and in writing.

3- The researcher reviewed previous related studies and noticed that many studies have been conducted to investigate students' weakness in grammar achievement and suggested different approaches to improve it; Ta'amheh (2014) used educational websites. Saker (2015) used jigsaw strategy and found it effective in improving learners' achievement in grammar and Jendaya(2016) used the 5Emodel (engagement-explorationexplanation-elaboration-evaluation). Previous studies on grammar revealed the persistence of actual problems, in our Egyptian classes, in teaching and learning grammar in general and in using grammar rules for oral or written expressions. Other studies like (Abou Shaaban et al., 2011; Rafik, 2012; El Basel, 2013; Al Mansouri ,2014; Bani Hani,2014; 
Emjawer ,2016) also discussed the importance of improving EFL achievement in grammar.

-Some previous studies also assured the importance of motivation in acquiring English as a foreign language and showed that lack of motivation affects the progress in acquiring the language skills such as the studies of (Tsai ,2013; Abdur Rehman ,2014; Ahmed, 2015; Aguirre, et al.,2016; Bedel ,2016; Wadho ,2016; Vibulphol ,2016).

-With reference to the problem of students' weakness in grammar achievement and the importance of motivation in learning English, contextualization using REACT (Relating, Experiencing, Applying, Cooperating, and Transferring) strategy could be an applicable strategy in teaching grammar. The stages of the strategy enable the teacher to present grammar in various real-life situations using authentic materials. REACT strategy was used widely and successfully in teaching math and science but not - as far as the researcher knows- in teaching EFL.

\section{Problem of the study}

The current study tackles the weakness of first secondary grade students' achievement in grammar and in their low motivation level. In an attempt to solve this problem, the researcher used context-based strategy REACT to identify its effect on developing first grade secondary students' achievement in grammar and motivation. The study also examined transfer of learning to the students' oral performance.

\section{Questions of the study}

The present study attempted to find answer to the following main question:

What is the effect of using context-based strategy REACT on developing first grade secondary students' achievement in grammar and motivation, and the transfer of learning on their oral performance?

From this main question the following sub-questions emerged:

1 - What is the suggested organization and form of first grade secondary grammar lessons using REACT strategy?

2- What is the effect of using REACT strategy on developing first grade secondary students' achievement in grammar?

3- What is the effect of using REACT strategy on developing first grade secondary students' motivation?

4- What is the effect of using REACT strategy on transfer of learning to first grade secondary students' oral performance? 


\section{Purpose of the study}

The purpose of the study was to develop first grade secondary students' achievement in grammar and motivation as well as examining the transfer of learning on their oral performance.

\section{Hypotheses of the study}

This study sought to verify the following hypotheses:

1- There will be a statistically significant difference between the mean scores of the grammar achievement test of the experimental and control groups in the post administration of the test in favor of the experimental group.

2- There will be a statistically significant difference between the mean scores of the experimental group in the pre and post administration of the grammar achievement test in favor of the post test.

3- There will be statistically significant differences between the mean scores of the experimental group in the pre and post application of the motivation questionnaire in favor of the post administration.

4- There will be statistically significant differences between the mean scores of the experimental group in the pre and post administration of the oral performance test in favor of the post test.

\section{Aims of the study}

The primary focus of this study was to determine the effect of using context-based strategy REACT proposed by Crawford (2001), on developing students' achievement in grammar and motivation. It also aimed at determining the transfer of learning grammar using REACT strategy on the students' oral performance.

\section{Variables of the study}

\section{1- Independent variable}

Using context-based strategy REACT to develop first grade secondary students' achievement in grammar and motivation and transfer of learning grammar on their oral performance.

\section{2- Dependent variable}

- First grade secondary students' achievement in grammar.

- First grade secondary students' motivation.

-First grade secondary students' oral performance. 


\section{Delimitations of the study}

The present study is delimited to:

1- Participants of first secondary grade students randomly nominated from Ismail El kabany secondary school for boys in Cairo in the first term of the academic year 2017-2018. First secondary grade students are supposed to have suitable mental and language maturity to acquire grammar in the light of context-based strategy REACT.

2- The grammar rules to be targeted are included in the students' textbook; the units from 1-9 which are: the present simple and the past simple- the past continuous and the past perfect- if conditional (zero-first and second conditionals) - the present perfect- the verb +infinitive or gerund-future forms- using (should- shouldn't- must- mustn't) - the third case if conditional and using the articles (a- an -the).

3-Motivation in the following four dimensions: self-efficacy- task valueextrinsic goals and achievement goals.

4- Oral performance in the areas of grammar and fluency.

\section{Significance of the study}

The significance of the present study springs from the following:

- Using context-based strategy REACT in teaching grammar to EFL learners. REACT strategy has been used widely in teaching math and science but not- as far as the researcher knows- in teaching EFL.

- Helping English language teachers to present grammar lessons using context-based strategy REACT. The strategy depends on using videos, graphs, pictures, songs, stories, imaginative situations and real life tasks. It leads to increasing the learners' achievement and improves their motivation as well.

- Emphasizing teachers' role in encouraging students to use grammar functionally by adopting suitable teaching strategies.

- Stimulating English language supervisors to organize training courses for English teachers to train them on using different context-based strategies.

-Providing English language specialists and curriculum designers with REACT strategy to be taken into consideration in planning and constructing activities for secondary stage English language students.

\section{Definition of terms}

The following terms refer to the operational definition in the current study:

REACT strategy: It is one of context-based learning strategies. It consists of five stages which are: relating, experiencing, applying, 
cooperating and transferring. It is used in the current study to present grammar rules for first year secondary stage students. It helps the learners to relate grammar content to the context of real life, experience the new knowledge, apply the new language in real-life situations, cooperate and communicate with others to answer different tasks and transfer the learnt information on other new contexts.

Transfer of learning: It refers to the students' ability to use the grammar rules - included in the first year secondary textbook ( the first term) presented to them using context-based strategy REACT in oral performance. It is measured by the marks the learners get in an oral performance test prepared by the researcher.

Motivation: It is the inner and outer drive and enthusiasm that encourage learners to do some efforts to learn English as a foreign language. In the current study the following motivation dimensions are measured: selfefficacy- task value- extrinsic goals and achievement goals.

Oral performance: It refers to the learners ability to express themselves orally with smoothness and continuity of discourse without hesitation (fluency) in different life situations using the target grammar rules presented to them using context-based strategy REACT appropriately (grammar).

\section{Theoretical background}

\section{(1)Context-based learning}

\section{Definition}

Context-based learning has been defined in previous studies and related literature. The following is a presentation of some of these definitions:

According to Hull (1995), contextual learning occurs when students process new information or knowledge in such a way that it makes sense in their frame of reference. He also adds that the mind naturally seeks meaning in context and does so by searching for relationships that make sense and appear useful.

Johnson (2002) and Powers \& Guan (2000) agree with the previous definition adding that in context-based learning the brain searches for the meaning of specific relationships with our surroundings with the help of context-based activities. They add that educators have to be clever to design learning environments that can be easily related to real life.

Sears (2002) defines context-based learning as a concept of learning which motivates the learners to take charge of their own learning and to relate between knowledge and its application to the various contexts of their lives. 
Bilgin et al. (2017) add that "context" may be a topic, problem, story, state, activity, game, trip or events we meet in daily life and can be used in learning. These "contexts" are enriched with texts, videos, discussions and classroom activities.

The current study benefited from the previous definitions in the reconstruction of the first grade secondary students grammar lessons using context-based strategy REACT. The activities related the learners' prior knowledge to new learning, everyday life situations were used and the learners were active in the learning process. The researcher also used authentic materials and enriched the activities with audio-visual aids.

\section{Context-based learning philosophy}

Context-based approach springs from the social constructivist theory, learning is explained by Vygotsky's theory emphasizing the importance of culture and language, and indicating that knowledge is constructed through social interactions (Wood, 1998; Fosnot, 2005;Gilbert, 2006; Nentwig et al., 2007; Bennett and Lubben, 2006).

According to Fosnot (2005) and Sumarmi (2012), constructivism learning is part of a contextual approach in which students prepare and develop their own understanding and comprehension of new experiences based on prior knowledge possessed.

One of the significant features of context-based teaching is the adoption of student-centered and active learning approach (Bennett et al., 2005). Learning ensures the importance of the learner's experience and that he should be the center of the learning process. Learning takes place when the learner constructs his learning himself. Learning in context stimulates the learner's brain to build connections between the gained knowledge and its applications.

When the learner relates the new information to prior knowledge in daily life context, learning becomes meaningful. Learners become motivated if they take part in the classroom activities, they learn better by experiencing and active learning.(Özbay \& Kayaoglu, 2015; Ültay, 2012; Crawford, 2001). The present study puts into consideration the basics of context-based learning in the design of the activities.

\section{The characteristics and importance of context-based learning}

The characteristics and importance of context-based learning can be summed in the following points:

-The learners become self-regulated and active in the learning process. Context-based learning improves their positive involvement in the activities. It helps the learners to be focused on the lessons and attracts 


\section{Hanan Ahmed Hussien}

their attentions to the topic of the lesson. They realize the value of what they learn in their lives (Ulusouy \& Onen, 2014; Utlay et al., 2015; Ultay \& Calik, 2016).

- The learners create connections between what they learn and real life. Ummels et al. (2015) mention that context- based learning helps the teachers to connect the academic content to real life situations which directs the learners to find relations between knowledge and their lives. It also helps them to acquire knowledge in a

-Davtyan (2014) states that context-based learning focuses on problem solving strategies and directs the learner's attention to solve the problems and questions they meet in daily life. Gilbert (2006) adds that contextbased learning enables the students to relate the topics with each other and see the usefulness of the new learnings in daily life, increasing students' interest and motivation.

\section{(2)REACT strategy}

\section{Definition}

REACT is a context-based strategy that enhances the interaction among learners and the other learners, learners and teachers and learning resources in a learning environment. According to REACT strategy learning is organized in an interactive, inspiring, fun, challenging, motivating the students to participate actively (Coştu, 2009; Ültay, 2012; Ültay, Durukan \& Ültay, 2014).

Bilgin et al. (2017) define REACT as a strategy that helps the teachers and students to create relations between the new learnt concepts and real life experience. It consists of five stages: Relating, Experiencing, Applying, Cooperating and Transferring.

The definitions of REACT strategy show that it embodies the principles of context-based learning. The stages of the strategy enable the teacher to present the target language in context.

\section{The stages of REACT}

The strategy consists of five stages:

1- Relating: Learning in the context of life experience - everyday sights, events, and conditions - allows learners to then relate those familiar situations to new information to be processed or problems to be solved (Johnson, 2002; Powers \& Guan, 2000 ; Crawford, 2001).

2-Experiencing: Learning in the context of exploration and discovery is the heart of contextual learning. Learners are encouraged to manipulate materials and reach conclusions themselves. Teachers help students construct new knowledge with hand-on experiences that occur inside the classroom (Bjornavold, 2000; Falk \& Dierking, 2000). 
3-Applying: Learning by using new concepts and information in a useful context allows learners to envision future. In contextual learning, applications are often based on occupational activities - ideally authentic, non-contrived, real-world tasks.. Teachers can motivate students by making problems realistic and relevant to students' life (Gerlai, 1998).

4- Cooperating: Learning in the context of sharing, responding, and communicating with others is a primary instructional strategy in contextual teaching. The experience of cooperating not only helps the majority of learners learn the material; it also is consistent with the realworld focus of contextual teaching. Working in groups helps students to solve complex problems with very little help (Powers \& Guan, 2000).

5-Transferring: Learning in the context of existing knowledge, or transferring, uses and builds upon what the learner already knows. Learning to transfer familiar information to new contexts helps learners approach unfamiliar situations and problems with confidence. In this stage the teacher helps students to take what they have learned and apply it to new situations and contexts (Lent et al., 2001;Bransford \& Cocking, 1999).

The previous stages of REACT strategy help the learners to identify their prior knowledge and relate it to the new knowledge using daily life events and situations. This leads to better understanding and improved achievement and consequently a better chance for the transfer of learning. They can apply the acquired knowledge in new situations and with other skills. The stages of the strategy also depend on presenting the information to the learners in social and cooperative context. The learners take part in the responsibility of their learning, they are motivated to learn.

\section{(3) Grammar}

Mclaughlin (2003) maintains that grammar can be defined as the rules by which words change form and are combined into sentences. Crystal (2004) expresses that grammar is the structural foundation of our ability to express ourselves. The more we are aware of how it works, the more we can monitor the meaning and effectiveness of the way we and others use language. Grammar enables the individual to deliver a clear message and understand and convey meaning correctly, whether in writing or orally (Azar, 2007).

\section{Approaches to Teaching Grammar}

There are several approaches to teaching grammar; the following is a presentation to some of them: 


\section{Hanan Ahmed Hussien}

Grammar as Product, Process and Skill:

A useful approach was presented by Batstone (1994), who differentiated among three approaches to teaching grammar: as a process, as a product and as a skill, where the first two are on the opposite sides of a continuum and the third provides means of transition from the initial first one to the desired second one.

Teaching Grammar Based on PPP:

In this situational approach, a three-phase sequence, known as the P-P-P cycle, was often employed: Presentation, Practice, and Production. During the presentation phase, the new grammar structure is presented. During the practice phase, students practice using the new structure in a controlled context, through drills or substitution exercises. During the production stage, students practice using the new structure in different contexts.

The Deductive Approach:

Thornbury (2012) defines the deductive approach as starting with the presentation of a rule and followed by examples in which the rule is applied. Deductive grammar teaching is based on facts and statements; it is also based on prior logic.

The Inductive Approach:

Thornbury (2012) defines the inductive approach as starting with some examples from which a rule is inferred. In place of terms, the inductive approach is also called as discovery learning.

The current study adopted the inductive approach in teaching the target grammar rules of the first grade secondary stage student's book. The inductive way suits the nature of the stages of REACT strategy; at the second stage -Experiencing-the teacher presents various examples and a passage from the students' book. The learners participate in inferring the rule under the teacher's guidance and supervision.

\section{Teaching grammar in context}

Context-based grammar holds an important place for effective learning. It will be more motivating for learners if grammar is taught in context as students will have an opportunity to perceive how the new grammar structures work. Grammar rules are also made easier if they are given in context and teaching grammar in context provides accuracy in the target language.

Nunan (1998) believes that teaching grammar in context provides opportunities for learners to explore grammatical structures; they make the task of developing procedural skill- being able to use the language for communication- more difficult than it needs to be, because learners are denied the opportunity of seeing the systematic relationships that exist 
between form, meaning, and use $\|$. In grammar instruction the goal is not to teach grammar rules but to teach how to apply them in language skills (Byrd, 2005).

Teaching grammar in context also provides a meaningful framework that connects to reality of the targeted language (Anderson, 2005). Many researchers stress the fact that learners need to experience grammatical conventions in various contexts in order to control and use them correctly. Context-based teaching will show learners how grammar structures function in context that will give them an opportunity to develop their comprehension of the grammar rules. In genuine communication beyond the classroom, grammar and context are often so closely related that appropriate grammatical choices can only be made with reference to the context and purpose of the communication (Nazil, 2011).

It can be concluded that teaching grammar in context shows the learners how the grammar structures work, improves their communicative abilities, connects grammar uses to reality and provides accuracy in both oral and written skills.

The following contexts are used to introduce various grammatical topics in the present study.

-Pictures / Charts / Graphs

- Video / Audio

- Stories / Personal Questions / Polls

- Problems / Situations

- Realia

- Real-life tasks Readings

- Dialogue / Role play

\section{(4) Motivation}

Motivation is a complicated psychological process. It starts with a need and leads to a behavior that helps move people towards achieving their goals (Melendy, 2008). Learners' motivation has become more commonly recognized as perhaps the major determining factor of successful learning in general The success of any action usually depends on the extent to which individuals strive to attain their purpose, along with their desire to do so (Utari, 2015).

\section{Kinds of motivation}

There are two different kinds of motivation: intrinsic and extrinsic. Intrinsic motivation comes from within and is associated with the joy or passion that the task gives the learner rather than any reward it brings 


\section{Hanan Ahmed Hussien}

(Irvin et al., 2007). Extrinsic motivation is something to do with external factors associated with the task such as assessment. External factors can also be related to instructional strategies, learning conditions, educational technologies and other elements in activity systems. Arends (2008) believes that intrinsic motivation is usually characterized by behavior that is internally driven by interest or curiosity in a certain way simply because it gives personal pleasure or satisfaction derived from an experience, whereas extrinsic motivation can be characterized by behavior of individuals action by external factors such as reward, punishment and social pressures that come from outside the action or activity.

Chen (2012) divides motivation into two parts; they are internal and external motivation. He states that there are four characteristics underlying the development of intrinsic motivation such as selfdetermination (the ability to predetermine the purpose of self-performed or which previously owned), curiosity (the tendency to learn and know inside out of something that is quite substantially within themselves, challenge (a chance to get something in accordance with the potentiality of self), and effort (a skill that mustered to achieve something according to his expectations), whereas extrinsic motivation is a form of stimulation in the condition from the people around him/her. He thinks that internal motivation tends to be last longer than external motivation.

The current study is delimited to four motivation axes: self-efficacytask value- extrinsic goals and achievement goals. They include both external and internal motivation. The chosen motivation axes are believed to suit secondary stage learners and the other variables of the study.

\section{Techniques to develop Motivation}

The following techniques are used to develop learners' motivation (Wang, 2008):

\section{Personal relevance \& interest}

First, the material must be seen as personally relevant, interesting, and useful to the learner. In practice, making the material relevant usually means finding ways to present it in terms of authentic real world situations and problems that the students can relate to. Showing how the material will be used in careers that they aspire to be is also motivational.

\section{Choice and control}

A second motivating element is for the learner to feel they have some degree of control over the learning process. Relatively modest amounts of control or choice can make a large difference in motivation. For example, allowing some choice of assignment topics or formats, and having 
projects where the student can choose a topic of particular interest to them.

Sense that one can master the material

The third general motivating factor is providing the learner with a sense that they can master the subject, and that they understand the process to follow to achieve that mastery. These are best addressed by having suitable levels of challenge in the course and providing clear feedback as to how well students are meeting those challenges.

The present study uses the previous techniques to increase first grade secondary stage learners' motivation. The stages of the context-based strategy REACT depend on using authentic and everyday life materials which arouse the learners' interest and increases their motivation. The learners also have the opportunity to choose the activity or situation they want at the stages of the strategy. The teacher presents feedback to the learners and uses cooperative learning techniques to improve the learners' motivation.

\section{(5)Transfer of learning}

\section{Definition}

Transfer of learning takes place between a learnt topic and a similar situation inside or outside the school (Carpenter, 2012). It requires realizing the relation between the previous experience and the current situation, then connecting the educational experiences together followed by relating them to other real life situations (Hinkell, 2001). Mayer (2002) adds that transfer of learning is the ability to use what we learn to solve new problems and answer new questions. It also facilitates learning new content.

Saavedra \& Opfer (2012) mention that transfer of learning means using previous knowledge in new learning. It refers to using information and skills of a field of knowledge to transfer it at another one; it is the learners' use of what they learn in school in their lives.

In the current study transfer of learning refers to first grade secondary students' application of the grammar structures presented to them using REACT strategy in expressing themselves orally in new similar situations.

\section{Levels of transfer of learning}

Devet (2015) and Calais (2006) identified the following six levels for the transfer of learning: 


\section{Hanan Ahmed Hussien}

1-Nonspecific transfer: It means that every learning occurs in our life is basically a transfer of learning; every new learning is related to the previous one.

2-Application transfer: It refers to applying the new learning in specific situation; for example after learning computer programming, this knowledge is applied on a computer.

3-Context Transfer: It means applying what has been learnt in new situations different slightly from the learning situations.

4-Near transfer: Near transfer occurs when a new situation resembles the situation in which the skill or knowledge was learned. Near transfer knowledge is usually repetitive, such as tasks that reproduce a process or procedure.

5-Far transfer: It occurs when the learner applies the learnt knowledge in situations which are different from the former educational situations. It is also called analogical reasoning. Far transfer tasks involve skills and knowledge being applied in situations that change. Far transfer tasks require instruction where learners are trained to adapt guidelines to changing situations or environments.

6- Creative transfer: This level is above realizing the similarities between situations, it is reaching a concept or using something new resulting from the interaction between new and old experience. Creative transfer includes fluency, flexibility and originality.

\section{(6)Oral performance}

\section{Definition and importance}

Oral performance is a crucial skill in learning a foreign language. It is very important to experience real communicative situations in which learners will learn how to express their own views and opinions and to develop their oral fluency and accuracy which are very essential for the success of second language communication (Astuti, 2013).

Developing students' oral performance demands classroom activities that allow them to exchange ideas with each other, express their opinions, and develop learning strategies and communication skills for successful negotiation (Karfa, 2007).Students' silence or lack of interaction in classes widely perceived as a serious problem. Thus teachers should constantly have in mind the objectives of providing students with oral activities in class and those students need stimuli to practice communication actively in the course addressing their needs (Cotter, 2007). Mita et al (2006) state that providing students with different oral activities in their English course will help them discover the importance of both grammatical and strategic competence; stimuli or attractors for encouraging them to develop their oral performance. 
Using context-based strategy REACT, in the present study, leads to improving the learners' oral performance. The strategy depends on using authentic and audio materials, cooperative techniques, various oral activities, instant feedback and many opportunities to the target grammar rules orally.

\section{Method}

\section{Design of the study}

The design of the current study is the quasi-experimental pre-post- test control group. Two intact classes were randomly chosen, one as the control group and the other experimental group.

\section{The participants}

The participants in the current study were two groups; experimental group and control group. Each group had 35 first grade secondary students- after excluding the students who were frequently absent- during the first term of the academic year 2017/2018. Two classes were chosen randomly from Ismail al Kabany secondary school for boys; students of the first class were chosen as experimental group while students of the other class were the members of the control group after being sure that they had the same achievement level in grammar by examining the results of their monthly exams.

\section{Tools of the study}

\section{Treatment materials:}

1- A teacher's guide to present the grammar lessons using REACT strategy.

2- Activity papers for the students.

\section{Measurement tools:}

1- A pre-post grammar achievement test.

2- A pre-post motivation questionnaire.

3- A pre-post oral performance test.

To answer the study questions, the following treatment procedures were followed:

1- Identifying the organization of the first grade secondary grammar lessons and reconstructing their content using context-based strategy REACT. *Choosing the content 


\section{Hanan Ahmed Hussien}

The content is the grammar lessons included in the first grade secondary student's textbook. It has nine units and each unit has one grammar lesson. The lessons cover the following grammatical structures:

-Unit one: the present simple and the past simple

- Unit two: the past continuous and the past perfect

- Unit three: if conditional (zero-first and second conditionals)

-Unit four: the present perfect

-Unit five: the verb +infinitive or gerund

-Unit six: The future forms

-Unit seven: using (should- shouldn't- must- mustn't)

-Unit eight: the third case if conditional

-Unit nine: using the articles (a- an -the)

*Reconstructing the content: Each unit in the student's book consists of five sections: listening passage, grammar, reading, critical thinking and communication skills. The part devoted to presenting grammar contains some examples and exercises about the grammar rule and statement of the rule on the right of the page under the title "Focus on grammar".

The content was reconstructed using context-based strategy REACT as follows:

Identifying the educational aims

The aims of teaching grammar lessons included in the first grade secondary student's book- first term- are:

- Presenting the grammar lessons to the learners using context-based strategy REACT, aiming at developing their achievement.

--Training the learners on using different stages of context-based strategy REACT.

- Improving the learners' motivation towards learning the English language grammatical structures.

-Examining the transfer of learning grammar on the learners' oral performance.

-Developing the discussion skills among the learners and with the teacher and encouraging them to communicate in English.

- Encouraging the learners to use authentic materials in practicing the target language, search for information on the internet and the school library.

Preparing the teacher's guide

The researcher prepared the teacher's guide to teach the grammar lessons using context-based strategy REACT. The guide includes introduction to context-based learning; its definition, historical background and advantages. It also presents the importance and steps of REACT strategy. The guide also highlights the importance of oral performance with reference to transfer of learning and encouraging students to 
communicate using the English language. It also gives general directions for the teacher to present the lessons and activities with the required teaching aids and materials. The guide explains in details the expected role of the teacher and the students at the strategy different stages. Distribution of the lessons and time plan are included.

Time plan for presenting the content

The presentation of the content lasted for 10 weeks (two months and half). The researcher met the learners once every week for 90 minutes (two school periods at the secondary school). The first period was devoted to explain context-based strategy REACT; its steps, the expected role of the learners and the importance of cooperating and participating effectively in the activities.

\section{Table (1) Time plan for presenting the grammar lessons}

\begin{tabular}{|c|c|c|c|}
\hline $\mathbf{N}$ & The subject & Time & Periods \\
\hline 1 & Introduction & 90 minutes & 1 \\
\hline 2 & $\begin{array}{l}\text { Unit one } \\
\text { The present simple/The past simple }\end{array}$ & 90 minutes & 1 \\
\hline 3 & $\begin{array}{l}\text { Unit two } \\
\text { The past continuous/The past perfect }\end{array}$ & 90 minutes & 1 \\
\hline 4 & $\begin{array}{l}\text { Unit three } \\
\text { If conditional( first and second cases) }\end{array}$ & 90 minutes & 1 \\
\hline 5 & $\begin{array}{l}\text { Unit four } \\
\text { The present perfect }\end{array}$ & 90minutes & 1 \\
\hline 6 & $\begin{array}{l}\text { Unit five } \\
\text { Verb infinitive/ Verb+ing form }\end{array}$ & 90 minutes & 1 \\
\hline 7 & $\begin{array}{l}\text { Unit six } \\
\text { Future forms }\end{array}$ & 90 minutes & 1 \\
\hline 8 & $\begin{array}{l}\text { Unit seven } \\
\text { Should/Shouldn't-must/mustn't }\end{array}$ & 90 minutes & 1 \\
\hline 9 & $\begin{array}{l}\text { Unit eight } \\
\text { The third conditional (if) }\end{array}$ & 90 minutes & 1 \\
\hline 10 & $\begin{array}{l}\text { Unit nine } \\
\text { Articles a/an/the }\end{array}$ & 90 minutes & 1 \\
\hline
\end{tabular}

Judging the teacher's guide: it was given to a jury after clarifying its aim and they were kindly asked to validate the appropriateness of the teaching procedures with the content and objectives of the guide, the suitability and adequacy of the activities( The jury who kindly validated the guide and tools of the study were four staff members from the Department of Curricula and Methods of Teaching, Girls' College, Ain Shams University and two staff members from other faculties). They suggested 


\section{Hanan Ahmed Hussien}

some modifications which were taken in consideration in the final version of the teacher's guide.

Preparing the students' activity papers

In the light of the aims and the content of the grammar lessons, the researcher prepared the students' activity papers according to contextbased strategy REACT. It included the different activities which were presented by the teacher to the class. Every activity is followed by the steps that should be followed by the learners and the necessary directions. Spaces for writing down the answers, notes or comments are supplied. Thus, the first sub-question of the study is answered.

* Application of the strategy

Before starting to present the grammar lessons using context-based strategy REACT, the researcher met the English teacher of the experimental class. He has been teaching secondary stage for 8 years. The purpose was to explain REACT strategy, its philosophy, stages, importance and teaching procedures. The teacher was enthusiastic and hoped to improve the students' achievement in grammar. The teacher was given the teacher's guide which included the grammar lessons presented using REACT strategy. The researcher also explained to the teacher the expected improvement in the learners' motivation. The researcher directed the teacher's attention to the importance of giving the students the opportunity to communicate orally using the target grammar rule as indicated in the teacher's guide. The researcher met the teacher regularly every week. The control class studied the grammar lessons with another teacher who has been teaching English for 6 years. He taught them using the traditional way.

The following is a model of presenting grammar using REACT strategy: In presenting lesson two "the present and past simple"; the following steps are followed:

1- Relating

This stage aims at arousing the learners' curiosity and motivation to learn. The teacher usually uses authentic material at this stage. The teacher plays two short videos, the first one describes the daily routine of the queen of the United Kingdom and the second one is about the life and work of the late famous Egyptian scientist Ahmed Zewail. The videos are accompanied by written sentences. This is followed by an activity in which the teacher asks the students to talk about their daily routine, then they are asked to mention the names of famous Egyptian characters that were discussed in the reading and listening passages in unit one(students' textbook). The learners are expected to demonstrate their prior knowledge about the rule and realize the relation between it and everyday life situations. 


\section{2- Experiencing}

This stage aims at directing the learners to induce the grammar rule before the teacher explains it. The teacher uses the overhead projector to display a passage from the students' book about Dr.Farouk El-Baz. The teacher extracts different sentences from the passage and asks the students to take part in identifying the forms and uses of the two tenses (present and past simple). The teacher then explains the rule using examples from the students' life to highlight the difference between the present and past simple. The learners are active in inducing the rule and writing notes about them.

\section{3- Applying}

This stage aims at presenting different activities and questions to check the learners' understanding of the rule. Real life activities are presented. The learners are asked to work individually and mention sentences about their mother's daily routine and then answer another activity about the present and past tense (teacher's guide p.12). The activity has 10 multiple choice questions. The learners are expected to answer the activities as application of the gained information from the lesson. Feedback is presented by the teacher.

\section{4- Cooperating}

This stage aims at presenting various activity problems and everyday life situations for learners to work in groups to answer them. In this lesson, the learners work in groups to talk about a living famous Egyptian character or a dead one.

\section{5-Transferrring}

This stage aims at helping learners to use the knowledge they gain from the lesson to answer problems and issues from life related to the lesson. Tasks presented at this stage are usually challenging. The teacher presents different pictures from the Egyptian museum and ask students to volunteer; one as a tourist guide and the others as tourists. They exchange questions and answers about Pharos' life and comparing it to our present life using the present and past simple. The teacher gives feedback and encourages creative answers.

At the end of the lesson the teacher directs them to answer exercises about the present and past simple in their activity papers.

\section{2- Constructing the tools of the study}

The following steps were followed to design and construct the measurement tools of the study.

\section{a- A pre -post grammar achievement test.}

The grammar achievement test was constructed in the light of the following procedures: 


\section{Hanan Ahmed Hussien}

1- Reviewing the Ministry of Education directives concerning the aims of teaching grammar for the secondary stage.

2- Examining the grammar lessons in the student's book to identify the content and the learning objectives to be measured.

3- Identifying the division and shape of the first grade secondary stage grammar exam according to the Ministry of Education.

The aim of the test: It aimed at pre-post measuring achievement in grammar for first grade secondary students -the first term- of the members of both the experimental and control groups of the current study.

Constructing the test: the test consisted of 3 questions $(3 \times 10=30)$, the first question had ten multiple choice sentences. The second question also contained ten sentences that required rewriting using the word(s) in brackets to give the same meaning. The third question had ten sentences and the students were asked to find the mistake in each one and write it correctly.

Test validity: the first version of the test was submitted to jury members to evaluate the test in terms of (a) number of questions and appropriateness to the content and (b) suitability of the test to the first secondary graders. The jury members made some modifications which were taken seriously into consideration and were done accordingly. After the modifications were made, the test was mostly a valid one, as it showed that it measured what it was intended to measure as stated by the jury.

Test reliability: The test retest method was used to determine the reliability of the test. The test was administered to 35 first grade secondary students in Al Abassia secondary school for girls and was re administered by an interval of fifteen days to the same group. Then, the Pearson Correlation Coefficient between the test/re-test was calculated. The reliability coefficient was 0.89 which is relatively high .So, the test was reliable.

Timing the test: During piloting the test on the same 35 students, the researcher could decide the timing of the test. The following formula was used: (summation of the time taken by all the students) / (the number of the students) $=2100 / 35=60$ minutes

Scoring the test: The total mark of the test 30 marks, they were divided equally among the questions on the test. Ten marks for each question and one mark for every sentence.

\section{b- A pre-post motivation questionnaire.}

The following points were considered before constructing the motivation questionnaire:

1- Reviewing the literature about motivation. 
2- Reviewing previous studies related to improving motivation, especially those that are concerned with secondary stage students.

3- Reviewing some motivation questionnaires and scales.

The questionnaire was designed as follows:

The questionnaire aimed at identifying the effect of using context-based strategy REACT in teaching the grammar lessons of first year secondary grade on improving their motivation.

Constructing the questionnaire: the questionnaire had four dimensions (self-efficacy- task value- extrinsic goals- achievement goals). The items of the questionnaire were statements which indicated the students' use of the four previous dimensions. The questionnaire had some positive and negative statements. Instructions for the learners were clearly written before starting the questionnaire.

Table (2) description of motivation questionnaire

\begin{tabular}{|l|l|l|l|l|}
\hline & $\begin{array}{l}\text { Motivation } \\
\text { domain }\end{array}$ & $\begin{array}{l}\text { Positive } \\
\text { statements }\end{array}$ & $\begin{array}{l}\text { Negative } \\
\text { statements }\end{array}$ & Total \\
\hline $\mathbf{1}$ & Self-efficacy & $1-2-3-4-5$ & $6-7-8-9-10$ & 10 \\
\hline $\mathbf{2}$ & Task value & $\begin{array}{l}11-12-13-14-15- \\
16\end{array}$ & $17-18-19-20$ & 10 \\
\hline $\mathbf{3}$ & Extrinsic goals & $\begin{array}{l}21-23-25-26-29- \\
30\end{array}$ & $22-24-27-28$ & 10 \\
\hline $\mathbf{4}$ & $\begin{array}{l}\text { Achievement } \\
\text { goals }\end{array}$ & $32-34-36-38-40$ & $31-33-35-37-39$ & 10 \\
\hline & & $\mathbf{2 2}$ & $\mathbf{1 8}$ & 40 \\
\hline
\end{tabular}

The design and correction of the questionnaire: The total number of statements was 40. Every statement had three responses (AlwaysSometimes- Never).In scoring the questionnaire the positive statement was given the marks (3-2-1) and the negative one is given the marks (1-23). The total mark of the questionnaire was 120 marks and the minimum mark was 40 marks.

The questionnaire validity: it was given to the jury members to give their opinion about the following:

1- The clarity of the questionnaire instructions.

2- The suitability of the scale items for first secondary graders.

3 - The belonging of each item to its domain.

4- The deletion or addition of items.

The jury members gave their instructions to change some statements which were done before preparing the final version of the questionnaire. They agreed on the suitability and validity of the questionnaire. 


\section{Hanan Ahmed Hussien}

Pilot application of the questionnaire: The questionnaire was applied in its final form on a group of 35 third grade preparatory students in $\mathrm{Al}$ Abassia secondary school for girls twice with the interval of two weeks to achieve reliability. Holsti formula was used and the agreement was 0.91 which is an accepted rate. The average time taken to finish the questionnaire was 45 minutes.

\section{c- A pre-post oral performance test}

The aim of the test: It aimed at pre-post measuring the experimental group members' oral performance in two skills; grammar and fluency.

Constructing the test: the test has four components.

1- Pictures: the test had ten colored pictures that presented different life situations. The topics of the pictures were earlier presented to the learners in the activities while explaining the grammar lessons using REACT strategy. The topics of the pictures were: daily routine, working as a tourists guide in the Egyptian museum, fairy tales, travelling into space, life in the future, attending a wedding, hobbies, a famous movie poster, pets and wars. The students had the chance to choose the picture they can talk about. The pictures were used to motivate the learners and arouse their interest to speak.

2-Guiding questions: some questions were prepared by the researcher for each picture to help and promote the learners to speak. The questions also gave them more ideas about the topics of the picture. It helped them to continue speaking.

3-A rating scale: the scale was designed to assess the two target skills; grammar and fluency. Each skill had five levels from 1-5 which indicates the learner's mark on each item.

4-Tape-recording: a tape- recorder was used to record the students' oral responses about the pictures they have chosen. This procedure enables the researcher and the other rater to rate the students' performance later.

Test validity: the oral performance test was submitted to jury members in its primitive version to evaluate the test in terms of (a) suitability of the test to first year secondary graders (b) appropriateness of the pictures and guiding questions and (c) suitability of the rating scale. The jury members made some modifications such as changing the picture about war, adding more guiding questions and changing some words in the statements of the scale. They were taken seriously into consideration and were done accordingly. After the modifications were made, the test was mostly a valid one, as it showed that it measured what it was intended to measure as stated by the jury.

Test reliability: Inter-rater reliability was used. It was estimated by examining the scores of two raters; the researcher and the experimental 
group teacher. Pearson correlation was used where $r=0.88$ which showed reliability of the test and consistency between the raters.

Timing the test: the test lasted fifteen minutes for each student, five minutes to decide which picture to talk about, five minutes to think and arrange ideas and five minutes to speak.

Scoring the test: the total mark of the test was ten; five marks for each skill (grammar and fluency). The learners' performance in the test was recorded. Rating scale was used to score the students' recordings. The researcher and the experimental group's teacher administered and scored the test. They gave every student a separate mark on each of the target skills (grammar and fluency). Each learner's mark was calculated by adding the total marks given bythe two raters and dividing it by two.

Grammar rating scale:

5- No grammatical or word order errors.

4- Good use of English with few grammar errors without effect on the meaning.

3- Sometimes grammar errors which cause misunderstanding.

2- Misuse of verb tenses and many word order mistakes.

1- Speech full of grammatical mistakes and word order errors which make comprehension difficult.

Fluency rating scale:

5-Speech is near to that of a native speaker with the ability to express ideas easily.

4- Speech is reasonable to some extent with the ability to express ideas with some hesitation.

3-Speech and fluency affected by language problems but communication is possible.

2- Speaking with great difficulty, much hesitation and too much silence because of language hesitation.

1- Producing meaningless words and inability to communicate ideas.

\section{Data analysis}

\section{The first hypothesis}

There will be a statistically significant difference between the mean scores of the grammar achievement test of the experimental and control groups in the post administration of the test in favor of the experimental group.

After the post administration of the grammar achievement test on both the experimental and control groups, t-test for independent sample was used to compare the results as follows: 
Table (3) t-test results of the post administration of the grammar achievement test on the experimental and control groups

\begin{tabular}{|l|l|l|l|l|l|l|l|}
\hline Group & N & M & S.D & $\begin{array}{l}\text { Differen } \\
\text { ce } \\
\text { between } \\
\text { means }\end{array}$ & $\begin{array}{l}\text { Degree } \\
\text { of } \\
\text { freedo } \\
\text { m }\end{array}$ & $\begin{array}{l}\text { t- } \\
\text { valu } \\
\text { e }\end{array}$ & $\begin{array}{l}\text { Significan } \\
\text { ce level }\end{array}$ \\
\cline { 1 - 4 } $\begin{array}{l}\text { Experiment } \\
\text { al }\end{array}$ & 35 & 26.38 & 2.40 & 9.48 & 68 & $\begin{array}{l}22.1 \\
4\end{array}$ & $\begin{array}{l}0.01 \\
\text { Significanc } \\
\text { e }\end{array}$ \\
\cline { 1 - 3 } & 3 & $\begin{array}{l}16.9 \\
\text { Control }\end{array}$ & $\begin{array}{l}4.1 \\
1\end{array}$ & & & & \\
\hline
\end{tabular}

Table (3) shows that the mean scores of the experimental group in the post administration of the grammar achievement test (26.38) is more than the mean scores of the control group (16.90). The difference is (9.48) marks in favor of the experimental group. The above table shows that the estimated t-value (22.14) is statistically significance at 0.01 level. The effect size is large (7.34). Thus it can be safely said that there is a statistically significant difference between the mean scores of the grammar achievement of the experimental and control group in favor of the experimental group. This shows that the members of the experimental group developed their achievement in grammar more than those of the control group due to using context-based strategy REACT.

\section{The second hypothesis}

There will be a statistically significant difference between the mean scores of the experimental group in the pre and post administration of the grammar achievement test in favor of the post test.

After the pre-post administration of the grammar achievement test to the experimental group, $\mathrm{t}$-test for paired sample was used to compare the results as follows:

Table (4) t-test results of the pre-post administration of the grammar achievement test on the experimental group

\begin{tabular}{|c|l|l|l|l|l|l|l|}
\hline Application & $\mathbf{N}$ & $\mathbf{M}$ & S.D & $\begin{array}{l}\text { Difference } \\
\text { between } \\
\text { means }\end{array}$ & $\begin{array}{l}\text { Degree } \\
\text { of } \\
\text { freedo } \\
\mathbf{m}\end{array}$ & t-value & $\begin{array}{l}\text { Signific } \\
\text { ance } \\
\text { level }\end{array}$ \\
\hline post-test & 35 & 26.38 & 2.40 & 19.23 & 34 & 35.61 & $\begin{array}{l}00.1 \\
\text { significa } \\
\text { nce }\end{array}$ \\
\hline pre-test & 35 & 7.15 & 4.19 & & & & \\
\hline
\end{tabular}


Table (4) shows that the mean scores of the experimental group in the post administration of the grammar achievement (26.38) is higher than the mean scores of the pre administration of the test (7.15). The difference is (19.23) marks in favor of the post-test.

The above table shows that the estimated t-value (35.61) is statistically significance at 0.01 level. The effect size is large (6.4). Thus it can be safely said that there is a statistically significant difference between the mean scores in the pre and post administration of the grammar achievement test to the experimental group in favor of the post administration. The members of the experimental group developed their achievement in grammar after the application of context-based strategy REACT. Thus the second hypothesis of the study was verified and the second sub- question of the study was answered.

\section{The third hypothesis}

There will be statistically significant differences between the mean scores of the experimental group in the pre and post application of the motivation questionnaire in favor of the post administration.

After the pre-post administration of the achievement questionnaire on the experimental group, $\mathrm{t}$-test for paired sample was used to compare the results as follows:

Table (5) t-test results of the pre-post application of the motivation questionnaire on the experimental group

\begin{tabular}{|c|c|c|c|c|c|c|c|}
\hline \multirow[b]{2}{*}{$\begin{array}{l}\text { Motivation } \\
\text { dimension }\end{array}$} & \multirow{2}{*}{$\begin{array}{l}\text { The } \\
\text { mark }\end{array}$} & \multicolumn{2}{|l|}{ Post } & \multicolumn{2}{|l|}{ Pre } & \multirow[t]{2}{*}{ t-value } & \multirow[t]{2}{*}{ Effect size } \\
\hline & & $\mathbf{M}$ & S.D & $\mathbf{M}$ & S.D & & \\
\hline Self-efficacy & 30 & 27.14 & 1.98 & 16.71 & 3.25 & 7.85 & 2.97 \\
\hline Task-value & 30 & 25.76 & 1.14 & 15.35 & 2.95 & 9.74 & 2.50 \\
\hline $\begin{array}{l}\text { Extrinsic } \\
\text { goals }\end{array}$ & 30 & 26.33 & 1.77 & 14.87 & 2.74 & 8.48 & 2.74 \\
\hline $\begin{array}{l}\text { Achievement } \\
\text { goals }\end{array}$ & 30 & 26.50 & 1.76 & 16.65 & 3.17 & 7.67 & 2.30 \\
\hline Total & 120 & 105.75 & 3.65 & 63.58 & 7.45 & 9.98 & 3.11 \\
\hline
\end{tabular}

Table (5) shows that the mean score of the experimental group in the post application surpass the mean score of the pre application in each habit of mind in the questionnaire as follows:

1- The mean score for the post application in self-efficacy is (27.14), while the mean score for the pre application is (16.71). The t-value is (7.85) which is statistically significant at 0.01 level. The effect size is large (2.97). 


\section{Hanan Ahmed Hussien}

2- The mean score for the post application in task value is (25.76), while the mean score for pre application is (15.35). The t-value is (9.74) which is statistically significant at 0.01 level. The effect size is large (2.50).

3 - The mean score for the post application in extrinsic goals is (26.33), while the mean score for the pre application is (14.87). The t-value is (8.48) which is statistically significant at 0.01 level. The effect size is large (2.70).

4- The mean score for the post application in achievement goals is (27.50), while the mean score for the pre application is (16.65). The tvalue is (7.76) which is statistically significant at 0.01 level. The effect size is large (2.30).

It is concluded that there are statistically significant differences between the pre and post mean scores of the questionnaire on each motivation dimension: self-efficacy, task-value, extrinsic goals and achievement goals in favor of post application. The effect size was large for each motivation dimension. The result assures that using context-based strategy REACT had positive effect on developing the experimental group motivation. Thus the fourth hypothesis of the study was verified and the third sub- question of the study was answered.

\section{The fourth hypothesis}

There will be statistically significant differences between the mean scores of the experimental group in the pre and post administration of the oral performance test in favor of the post test.

After the pre-post administration of the oral performance test on the experimental group, t-test for paired sample was used to compare the results as follows:

Table (6) t-test results of the pre-post administration of the oral performance test on the experimental group

\begin{tabular}{|l|l|l|l|l|l|l|l|}
\hline Application & $\mathbf{N}$ & $\mathbf{M}$ & $\mathbf{S . D}$ & $\begin{array}{l}\text { Difference } \\
\text { between } \\
\text { means }\end{array}$ & $\begin{array}{l}\text { Degree } \\
\text { of } \\
\text { freedom }\end{array}$ & $\begin{array}{l}\text { t- } \\
\text { value }\end{array}$ & $\begin{array}{l}\text { Significance } \\
\text { level }\end{array}$ \\
\hline Post-test & 35 & 8.87 & 3.45 & 4.34 & 34 & 15.29 & 0.01 \\
Significance
\end{tabular}

Table (6) shows that the mean score of the experimental group in the post administration of the oral performance test (8.87) is higher than the mean scores of the pre administration (4.53). The difference is (4.34) marks in favor of the post administration. The above table shows that the estimated t-value (15.29) is statistically significance at 0.01 level. The effect size is large (7.34). This shows that the members of the experimental group's 
The effect of using context- based learning strategy REACT on developing secondary stage students' achievement in grammar, motivation and the transfer of learning on their oral performance

oral performance developed due to transfer of learning when using context-based strategy REACT in teaching grammar.

Thus the fourth hypothesis of the study was verified and the fourth sub question of the study was answered. The main question of the study was also answered and the aims of the study were achieved.

\section{Discussion of the results}

The results of the study showed that using content-based strategy REACT had positive effect on developing the learners' achievement in grammar and motivation as well as transfer of learning on their oral performance.

Firstly, the results of the achievement test and motivation questionnaire.

REACT strategy is learner-centered; it encourages the learner to be positive and active in the learning process. The learners cooperate at the stages of the strategy which encourages them to exchange information and help each other. They work in groups or pairs which creates friendly and motivating atmosphere.

The stages of REACT contributed to improving the learners' achievement in grammar and motivation as follows:

Relating the new experience to students' prior knowledge, everyday life" and their subject context.

Experiencing which provides opportunities for students to guess the grammar rule and take part in learning by doing through exploration activities to develop their intuition.

Applying which provides opportunities for students to perform learning by putting the concept to use.

Cooperating encourages students to cooperate in the context of sharing responding, and communicating with other learner.

Transferring encourages students to answer exercises and solve problems beyond what they have learned.

The learners are exposed to authentic samples of language so that the grammatical features being taught are encountered in range of different linguistic and experiential contexts. The learners study in a threatless environment which encourage them to think freely. The use of different audio and visual teaching materials such as videos, cartoon, pictures, charts, and graphs attributed in attracting the learners' attention and increasing their achievement.

The teacher's role as facilitator, instructor and guide has a positive contribution in developing the learners' achievement in grammar. The teacher also always presents feedback and encourages the learners to participate. 


\section{Hanan Ahmed Hussien}

The results of the present study agree with those of (Ültay et al., 2011; Demir \& Demircioglu,2012; Ultay et al., 2015; Bahtaji ,2015; Ültay \& Calik, 2016) in developing the learners' achievement using REACT strategy . Previous studies also show that context-based learning is used effectively in improving achievement; (Nazil, 2011; Wandasari, 2011; Kazeni \& Onwa, 2013; Ulusoy \& Onen, 2014; Ummels et al.,2015) .

The results of the current study also agree with other studies which attempted improving motivation using different strategies; (Tsai ,2013; Abdur Arehman ,2014; Ahmed ,2015; Aguirre et al.,2016; Khan et al., 2016; Wadho ,2016; Vibulphol,2016; Namazian,2017).The previous studies showed the effect of using songs, commuter-based activities, natural classroom setting and the teacher and parents' role in developing English language learners' motivation.

Secondly, the results of the oral performance test

The results of the oral performance test showed that using REACT strategy in teaching grammar has positive effect on the transfer of learning on the learners' oral performance. The stages of REACT strategy depends on the oral interaction among the learners especially at the last three stages (applying-cooperating and transferring). The teacher encourages the learners to interact orally using the target grammar rule.

The learners are encouraged to speak in a threat less environment where the teacher directs them to express themselves freely using the target grammar rule. The use of different audio and visual teaching aids such as videos, cartoons, pictures, charts, and graphs encourages the learners to express themselves orally (Astuti, 2013). The stages of REACT depend on cooperative techniques which direct the learners to interact orally to answer the exercises.

The oral performance test included pictures and situations similar to the activities presented at the stages of the REACT. Transfer of learning on the learners' oral performance test is delimited only to grammar and fluency. The researcher believes that measuring the two chosen skills is appropriate for the variables, duration and content of the current study.

Some studies investigated the transfer of learning; (Egan ,2004; Jones et al. 2012; Martini,2014; Buker ,2016). The results showed positive transfer of learning. In his study, Bahtaji (2016) improved transfer of learning through designed context-based instructional materials. The results showed that transfer of learning on different skills occur when the appropriate strategies and materials are used. 
The effect of using context- based learning strategy REACT on developing secondary stage students' achievement in grammar, motivation and the transfer of learning on their oral performance

\section{Recommendations}

In the light of the results of this study, the following recommendations are made:

a-For teachers:

- Teaching grammar through context to help learners perceive the structures of the language effectively. If learners are given grammatical structures in context, they will be able to use it functionally in communication.

- Using authentic language and different audio and visual aids in presenting grammar motivate the learners to use it in communication and to appreciate its value. It also improves their achievement in grammar.

-Using context based strategies such as REACT may help in improving the learner's achievement and motivation. Context-based learning activities should be integrated with EFL secondary stage text books.

- Impending pair and group work in the classroom activities urge learners to cooperate, to use the language in communication and increases their motivation.

- Creating friendly and threat less atmosphere in the classroom motivates the learners and increases their achievement. The teacher's role as facilitator and guide is recommended.

- Improving the learners' oral skills should be given considerable interest. Learners should use the target language in oral communication.

b- For curriculum designers:

- Preparing teachers' guide based on context-based strategy REACT to present different English language skills.

- Training in service secondary teachers on planning lessons using context-based strategy REACT.

\section{Suggestions for further studies}

- Investigating the effect of using context-based strategy REACT on improving different language skills like reading and writing.

-Examining the effectiveness of using context-based strategy REACT with the primary and preparatory stages.

- Improving students' achievement and use of grammar using various strategies depending on life, authentic and meaningful situations.

- Developing and measuring EFL learners' motivation at different education levels using different strategies.

- Examining the transfer of learning impact on different language skills.

- Developing students' oral performance and encourage oral discussion and self-expression. 


\section{Hanan Ahmed Hussien}

\section{References}

Abdur Rehman, M. (2014). The Role of Motivation in Learning English Language for Pakistani Learners. International Journal of Humanities and Social Science, 4(1), 105-117.

Abou Shaaban,M. et al.(2011).The effect of teaching grammar in writing contexts to enhance using grammar functionally for eleventh graders in Gaza Governate, Dissertations, http://search.mandumah.com/Record/542253.

Aguirre, D., Bustinza, D., and Garvich, M. (2016). Influence of Songs in Primary School Students' Motivation for Learning English in Lima, Peru. English Language Teaching; Published by Canadian Center of Science and Education, 9 (2), 240-251.

Ahmed, M. (2015). Students' Motivation toward English Language Learning at Undergraduate Level. Advances in Language and Literary Studies. Australian International Academic Centre, Australia, 6 (3), 75-80.

Akbulut, Y. (2007). Effects of multimedia annotations on incidental vocabulary and reading comprehension of advanced learners of English as a foreign language. Instructional Science, 35(20), 499-517.

Al Jamal, D.A. (2016). An imaginative approach to teaching grammar. ACI, EduSearch. http://search.mandumah.com/Record/735355.

Al Mansouri,N. (2014).The teaching of English grammar in Morrocan Universities: an alternative approach. ACI, Arabase, http://search.mandumah.com/Record/592941.

Anderson, K.L. (2005). Effect of participation in reflective writing program on middle school student Academic self - efficacy and self - regulated learning strategy use, Doctoral Dissertation, University of Colorado: Denver.

Arends, R. I. (2008). Learning to teach contextually 1. McGraw Hill, New York.

Astuti, D. K. (2013). The Gap between English competence \& performance (Performance: The learners' speaking ability. Proceedings of the $3^{\text {rd }}$ international conference on foreign language teaching and learning. Language Institute, Thamasat University, Indonesia; pp. 660-671.

Azar, B. (2007). Grammar-Based Teaching: A Practitioner's Perspective. TESL-EJ. 11(2). 1-12 Retrieved September 12, 2012 from http://www.tesl-ej.org/ej42/a1.pdf

Bahtaji,M.A.(2015).Improving transfer of learning through designed contextbased instructional materials. European Journal of Science and Mathematics Education Vol. 3, No. 3, 2015, 265-274.

Bani Hani,N.A.(2014). The effect of using computer in teaching grammar to the Jordanian University students. ACI,EduSearch, http://search.mandumah.com/Record/624455.

Barker, V. (1999). Students' reasoning about chemical reactions: What changes occur during context-based post-16 chemistry courses. International Journal of Science Education, 21(6), 645-665. 
Bastone, R. (1994). Grammar. Oxford: Oxford UP.

Beaten, M. et al. (2010). Using student - centered learning environment to stimulate deep approaches to learning: factors encouraging or discouraging their effectiveness. Educational Research Review, 5, 243260.

Bedel, E.F. (2016). Exploring academic motivation, academic self-efficacy and attitudes toward teaching in pre-service early childhood education teachers. Journal of Education and training studies, 4 (1), 1-8.

Bennett, J. \& Lubben, F. (2006). Context - based chemistry: the salters approach. International Journal of Science Education, 28 (9), 999-1015.

Bennett, J., Grasel, C., Parchmann, I., \& Waddington, D. (2005). Contextbased and conventional approaches to teaching chemistry: comparing teacher's views. International Journal of Science Education, 27(13).

Berns, R. \& Erickson, P. (2001). Contextual teaching and learning: Preparing students for the new economy. Retrieved on 12-12-2011 from (http://www.cord.org/uploadedfiles/NCCTE_Highlight

Bilgin, A.K., Yurukel F.N. \& Yigit, N. (2017): The effect of a developed REACT strategy on the conceptual understanding of students: "particulate nature of matter. Journal of Turkish science education, 14 (2), 65-18.

Bjoravold, J. (2000). Making learning visible: identification, assessment and recognition of non-formal learning in Europe: Eric.

Bossard, C. (2008). Transfer of learning in virtual environments: Anew challenge or virtual reality DOI 10.1007/s10055-008-0093-y, springer, $1-14$.

Bransford, J. A. D., Brown, L. \& Cocking, R.R. (1999). How people learn: Brain, mind, experience, and school. Washington, DC: National Academy Press.

Buker, L. (2016). Determinants of Transfer of Training: A Comprehensive Literature Review. International Journal for Research in Vocational Education and Training (IJRVET) Vol. 03, Issue 02, August 2016, 127 165.

Byrd, P. (2004). Grammar in the foreign language classroom: Making principal choices, Grace Stovall Burkart, Ed.; Washington, DC: Center For Applied Linguistics. Retrieved on June 30, 2014. From http://www.sadlier-oxford.com/

Byrd, P. (2005). Instructed Grammar. In Eli Hinkel (ed.), Handbook of Research in Second Language Teaching and Learning, 545-563. New Jersey: Lawrence Erlbaum Associates.

Caine, R.N. \& Caine, G. (1993). Making Connections: Teaching and the human brain. Alexandria, VA: Association for Supervision and Curriculum Development. 


\section{Hanan Ahmed Hussien}

Calais, G.J. (2006). Haskell's taxonomies of transfer of learning: implications for classroom instruction. National forum of applied educational research journal, 20 (3), 1-8.

Carpenter, S.K. (2012).Testing enhances the transfer of learning Association for psychological science, 21 (5), 279-283.

Chen, J.C. (2012).The effects of authentic audience on English as a second language(ESL) writers: A task-based, computer-meditated approach. Computer -assissted Language training 25(5).

Coştu, S. (2009). Teacher experiences from a learning environment based on contextual teaching and learning in mathematics teaching. Unpublished master dissertation, Karadeniz Technical University, Trabzon.

Cotter, Ch. (2007). Speaking well - Four steps to improve your ESL EEL students speaking ability. Retrieved from http://ezinearticles.com/7Speaking-Well-Four-Stcps- $\quad$ To-ImproveYourESLEFL- Students-Speaking- Ability\&id=631232.

Crawford, L.M. (2001). Teaching contextual: research, rational and techniques for improving students motivation and achievement in mathematics and sciences. CORD publishing, Texas.

Crystal, D. (2004). Words \& Deed. Retrieved from: http://www.davidcrystal.com.

Dean, D. (2008). Bringing grammar to life. Newark, DE: International Reading Association.

Demir, H. \& Demircioglu, G. (2012).The effect on a teaching material developed based on "REACT" strategy of gifted students. 31 (2), 101144, Ondokuz Mayis University.

Devet, B. (2015).The writing center and transfer of learning: a primer for directors. The writing center Journal, 35 (1), 119-136.

Egan, T. M. (2004). The effects of organizational learning culture and job satisfaction on motivation to transfer learning and turnover intention. Human Resource Development Quarterly, 15, 279\{301.

El Basel,R.A.(2013).Teaching grammar of English as a FI using a constructivism - $\quad$ based strategy.ACI,EduSearch, http://search.mandumah.com/Record/719225.

El Seoud, M. S. et al (2013).Implementation of Web-Based Education in Egypt through Cloud Computing Technologies and Its Effect on Higher Education. Higher Education Studies, v3 n3 p62-76.

Ellis, Rod. (2006). Current Issues in the Teaching of Grammar: An SLA Perspective. TESOL Quarterly. 40(1): 83-107.

Emjawer, S.M. (2016).An imaginative approach to teaching grammar.ACI,EduSearch, http://search.mandumah.com/Record/735355.

Falk, J. H., \& Dierking, L. D. (2000). Learning from museums: Visitor experiences and making of meaning: Al Tamira Press.

Fensham, P.J. (2009). Real world contexts in PISA science: implications for context-based science education. Journal of Research in Science Teaching, 46 (8), 884-896. 
The effect of using context- based learning strategy REACT on developing secondary stage students' achievement in grammar, motivation and the transfer of learning on their oral performance

Fink, D. (2003). Creating significant learning experiences: An integrated approach to designing college courses. Hoboken, NJ: Jossey Bass/Wiley.

Forero, Y. (2005). Promoting oral interaction in large groups through taskbased learning. Profile Issues in Teachers' Professional Development. 1(6). 73-82.

Fosnot, C. T. (2005). Constructivism: theory, perspectives and practice. New York: Tecaher College Press.

Gerlai, R. (1998). Contextual learning and cue association in fear conditioning in mice: A strain comparison and a lesion. Behavioral Brain Research, 95(2), 191-203.

Gilbert, J. K. (2006). On the nature of "context" in chemical education. International Journal of Science Education, 28(9), 957-976. doi:10.1080/09500690600702470.

Graff, N. (2010). Teaching rhetorical analysis to promote transfer of learning. Journal of Adoles-cent and Adult Literacy, 53(5), 376-385.

Guay, F., Chanal, J., Ratelle, C. F., Marsh, H. W., Larose, S., \& Boivin, M. (2010). Intrinsic, identified, and controlled types of motivation for school subjects in young elementary school children. British Journal of Educational Psychology, 80(4), 711-735.

Hadley, A.O. (2003). Teaching Language in Context. USA: Heinle \& Heinle.

Hameed,A.R. (2017).Using a Linguistic Theory of humor in Teaching English Grammar. English Language Teaching, v10 n2 p40-47 2017.

Harmer, Jeremy. (1991). The Practice of English Language Teaching. London: Longman.

Hartwell, P. (1997). Grammar, Grammars, and the teaching of Grammar crosstalk in Comp theory: A Reader. Ed. Victor Villanueva. Jr: Urbana.

Hinkel, E. (2004). New perspectives on grammar teaching in second language classrooms. Mahwah, NJ: L. Erlbaum.

Hull, D. (1995). Whoare you calling stupid? The revolution that's changing education: Corn Communications.

Imel, S. (2000). Contextual learning in adult education. Practice Application Brief, 12.

Irvin, J. L., Meltzer, J., \& Dukes, M. S. (2007). Taking action on adolescent literacy: An implementation guide for school leaders. http://www.ascd.org/publications/books/107034/chapters/

Jendeya, M. (2015).The Impact of 5E Model on Developing Tenth Graders' English grammar Learning and their Attitudes towards English. (Unpublished Master Dissertation), The Islamic University, Gaza Strip ، Palestine.

Johnson, B. E. (2002). Contextual teaching and learning: why it is and why it is here to stay. California: Sage Publications Ltd.

Jones, M. et al. (2012). The impact of collaborative and individualized students' response system strategies on learner motivation, 


\section{Hanan Ahmed Hussien}

metacognition and knowledge transfer. Journal of computer assisted learning, 28 (5), 471-487.

Karfa, A. (2007). Open classroom communication and the learning of citizenship values. English TeachingForum, 54(4), 16- 22.

Kazeni, M. \& Onwu, G. (2013). Comparative effectiveness of context based and traditional approaches in teaching genetics. African Journal of research in mathematics, science and technology education, 17 (1), 5062.

Larsen-Freeman, D. (2003). Teaching language: from Grammar to Grammaring .Boston, MA: Thomson Heinle.

Larsen-Freeman, D. (2009). Teaching and Testing Grammar. In Long, M.H. \& Catherine, J. Doughty (ed.), The Handbook of Language Teaching (pp. 518-542). Malde, MA: Wiley Blackwell.

Lent, R. W., Brown, S. D., Brenner, B., Chopra, S. B., Davis, T., Talleyrand, R., \& Suthakaran, V. (2001). The role of contextual supports and barriers in the choice of Math/ Science educational options:: A test of social cognitive hypotheses . Journal of counseling psychology.

Liu,M.(2007). Chinese students' motivation to learn English at the tertiary level. Asian EFL Journal 9(1).

Martini, T. (2014). The Transfer of Learning Associated with Audio Feedback on Written Work. The Canadian Journal for the Scholarship of Teaching and Learning: Vol. 5: Iss. 1, Article 8.

Massey, L. (2011). On the Richness of Grammar as an Analytical Lens in the Integrated Language Arts. English Journal, 100(4), 66-70.

Mayer, R.E. (2002). Rote versus meaningful learning. Theory into practice, 41 (4), 226-232.

Mazzeo, (2008). Supporting student success at California community colleges. Prepared for the Bay Area Workforce Funding Collaborative Career by the Career Ladders Project for California Community Colleges.

Mclaughlin, S. (2003). Strategies for teaching English. Al-Qattan Center for Educational research and Development.

Meledy K. (2015): Contextualized learning: what does the research date say? Institute for completion (IFC), citrus college, research brief N.1, November, 1-4.

Melendy, G. (2008). Motivating writers: The power of choice. The Asian EFL Journal, 10(3), 187-198. Retrieved from http://www.asian-efljournal.com/September_08_gm.php http://dx.doi.org/10.1111/14679922.00212.

Namazian,I.(2017).The effect of task-based language learning on motivation and grammatical achievement of EFL junior high school students. Advances in Language and Literary Studies ISSN: 2203-4714, Vol. 8 No. 2; April 2017

Nazil, I. (2011). The implementation of Contextual Teaching and Learning in English Lesson Plans for the First year Students of High School. 
The effect of using context- based learning strategy REACT on developing secondary stage students' achievement in grammar, motivation and the transfer of learning on their oral performance

(Unpublished Thesis). State Institute for Islamic Studies Salatiga,Central Java.

Nentwig, P., Demuth, R., Parchmann, I., Grasel, C., \& Ralle, B. (2007). Chemie im kontekt: stuating learning in relevant contexts while systematically devoloping basic chemical concepts. Journal of Chemical Education, 84(9), 1439-1444. doi:10.1021/ed084p1439.

Nilson, L. (2003). Teaching at its best: A research-based resource for college instructors. Bolton, MA: Anker Publishing.

Nunan, D. (1998). Teaching Grammar in Context. ELT Journal 52(2): 101-109. Richards, J. \& W. Renandya. (2002). Methodology in language Teaching. USA: Cambridge University Press.

Oxford Dictionary. (2013). Oxford Advanced Learners' Dictionary. Oxford University Press. http://oald8.oxfordlearnersdictionaries.com/dictionary/motivation\#motiv ate-43. Accessed 6 Jan. 2013.

Ozbay, A.S. \& Kayaoglu, M.N (2015). The use of REACT strategy for the incorporation of the context of physics into the teaching English to the physics English prep students. paper presented in the 2nd English studies conference 8-10 May 2015 in Karabuk University, 91-117.

Powers, S., \& Guan, S. (2000). Examining the range of student needs in in the design and development of a web-based course. Instructional and cognitive impacts of web-based education.

Rafik, M. (2012).Integrating the teaching of reading, writing and grammar in an EFL content.ACI,EduSearch, http://search.mandumah.com/Record/680598.

Raftery, B.S. (2015).Grammar Games: A Case for Instructionist Game Models to Enhance Grammar Awareness and Accuracy. Journal of Instructional Research, v4 p142-147.

Robbins, S. P.; Judge, T. A. (2007). Essentials of Organizational Behavior (9 ed.), Upper Saddle River, NJ: Prentice Hall, http://wps.prenhall.com 32.

Saavedra, A.R. \& Opfer, V.D. (2012). Teaching and learning 21st century skills: lessons from the learning sciences, Asia society partnership for global learning, Rand Corporation.

Saker, S.(2015). The effectiveness of Using Jigsaw Strategy on Palestinian Tenth Graders' English Grammar Learning. (Unpublished Master Dissertation), The Islamic University, Gaza Strip ,Palestine.

Sarac,H.S. (2018).Completing the Task Procedure or Focusing on Form: Contextualizing Grammar Instruction via Task-Based Teaching. College Quarterly, v21 n1 2018.

Sears, J. S. (2002). Contextual teaching and learning: a primer of effective instruction. USA: Phi Delta Kappa Educational Foundation.

Soleimani, H., \& Khandan, M. (2013). The effect of telling short stories on learning grammar among EFL high school students in Iran. International 


\section{Hanan Ahmed Hussien}

Journal of Language Learning and Applied Linguistics World, 4(2), $110-122$.

Sumarmi, V. (2012). Model-Model and contextual teaching, Aditya Media Publishing, Malang.

Ta'amneh, Mohammad (2014). The Effect of Using Educational Websites on First Year Students' Achievement in English Grammar. Badr Community college, Taibah University: Kingdom of Saudi Arabia.

Thomas, J. (2004). Guide to Managerial Persuasion and Influence. Upper Saddle River, N.J.: Pearson Prentice Hall, 2004. Print.

Thornbury, S. (2012). How to teach grammar. Harlow: Longman.

Tsai, C. (2013). The Study on Motivation and Anxiety Of English Learning Of Students At A Taiwan Technical University. International Journal of English Language Teaching. 1(1), 24-41, September 2013. Published by European Centre for Research Training and Development UK (www.eajournals.org).

Ulaty, N. (2015). The effect of concept cartoons embedded within contextbased chemistry: chemical bonding. Journal of Baltic science Education, 14 (1), 96-108.

Ültay, E., \& Ültay, N. (2014). Context-based physics studies: A thematic review of the literature. Hacettepe University Journal of Education, 29(3), 197-219.

Ultay, N. \& Calik, M. (2016). A comparison of different teaching designs of acids and bases subjects, Eurasia Journal of Mathematics, science and technology. Education, 12 (1), 57-86.

Ultay, N. et al. (2015). Evaluation of the effectiveness of conceptual change texts in the REACT strategy. Chemistry Education Research and Practice, 16, 22-38.

Ültay, N., \& Çalık, M. (2012). A thematic review of studies into the effectiveness of context-based chemistry curricula. Journal of Science Education and Technology, 21 (6), 686-701.

Ulusoy, F.M. \& Onen, A.S. (2014). A research on the generative learning model supported by context - based learning. Eurasia Journal of mathematics, science and technology Education, 10 (6), 537-546.

Ummels, M.H. et al. (2015). Promoting conceptual coherence within contextbased biology education. Science Education, 99 (55), 958-985.

Utari, S. (2012). Mathematical Reasoning and Communication Abilities. Educationist UPI.

Utomi, W.S. et al. (2016). React (relating, experiencing, applying, cooperative, transferring) strategy to develop geography skills. Journal of education and practice, 7 (17), 100-104.

Vibulphol, J. (2016). Students' Motivation and Learning and Teachers' Motivational Strategies in English Classrooms in Thailand. English Language Teaching; 9(4), 100-115 .Published by Canadian Center of Science and Education. 
The effect of using context- based learning strategy REACT on developing secondary stage students' achievement in grammar, motivation and the transfer of learning on their oral performance

Wadho, S. (2016). Motivation to Learn English language: A Survey on Parents' \&Teachers' Influence on L2 learners in Sindh, Pakistan. Advances in Language and Literary Studies, Australian International Academic Centre, Australia. 7 (4), 300-310.

Wandasari, T. (2011). Using contextual teaching and learning (CTL) in improving students' reading skill in procedural text. Undergraduate Paper of UPI. UPI Bandung: Unpublished.

Wang,X.(2008).Motivation and English achievement: An exploratory and confirmatory factor analysis of a new measure for Chinese students of English learners. North American Journal of Psychology,10 (3).

Weaver, C. (1996).Teaching Grammar in Context . Portsmouth, NH: Heine mann.

Webster,M. (2013). Merriam Webster. Merriam-Webster. http://www.merriam-webster. com/dictionary/motivation. Accessed 3 Jan. 2013

Wisniewska, D. (2013). Interest and interest-enhancing strategies of adolescent EFL learners. ELT Journal, 67(2), 210-219. http://dx.doi.org/10.1093/elt/ccs079.

Wood, D. (1998). How children think and learn. Oxford: Blackwell Publishers.

Zulmaulida, R. (2011). Contextual Teaching and Learning with REACT Strategy. [Available online] http://edmymatheducation.blogspot.com [March 24, 2011]. 